\title{
IgM monoclonal gammopathy and neuropathy in two siblings
}

\author{
TROELS S JENSEN, ${ }^{*} \dagger$ HENRIK D SCHRØDER, $\$$ VIGGO JØNSSON, \\ JAN ERNERUDH, $\|$ BENT STIGSBY, $\uparrow$ ZOFIA KAMIENIECKA, ** ERIK HIPPE,§ \\ WERNER TROJABORG†† \\ From the Departments of Neurology* and Clinical Neurophysiology, $\dagger \dagger$ Rigshospitalet, University of \\ Copenhagen, Institute of Pathology, $\ddagger$ University of Odense, Departments of Neurology, $\dagger$ Haematology $\S$ and \\ Clinical Neurophysiology, $\uparrow$ Gentofte Hospital, University of Copenhagen, Department of Neurology, $\|$ \\ University of Linköping, Sweden and Institute of Neurophysiology, ${ }^{* *}$ University of Copenhagen, Denmark
}

SUMMARY A sister and a brother with a progressive mixed axonal and demyelinating polyneuropathy were found to have a monoclonal IgM gammopathy of kappa and lambda type, respectively. Sural nerve and cutaneous nerve specimens obtained by biopsy showed deposits of IgM on myelin sheets. Sera from both patients contained antibodies directed to bovine peripheral nerve myelin as determined by ELISA technique and to normal human peripheral nerve myelin as demonstrated by indirect immunofluorescence histochemistry. These siblings may have a genetic predisposition to the formation of autoantibodies with peripheral nerve myelin as the target for the immune attack.

Peripheral neuropathy in association with lymphoproliferative disorders such as multiple myeloma, chronic lymphocytic leukaemia and malignant lymphomas is well known. ${ }^{1-4}$ Recent studies have shown that neuropathy also may occur in patients with monoclonal gammopathy of undetermined significance (MGUS), that is, without current signs of malignant lymphocytic or plasmocytic disease. ${ }^{5-8}$ Immunological studies have demonstrated in vivo binding of immunoglobulins to affected peripheral nerves of the same heavy and light chain types as those seen in the $\mathbf{M}$-component in the circulating blood. ${ }^{7910}$ The monoclonal immunoglobulins from patients with MGUS and neuropathy bind either to myelin of peripheral nerves or to connective tissue structures of the endoneurium. ${ }^{1112}$ Serum monoclonal immunoglobulin from patients with MGUS and neuropathy has also been shown to induce experimental demyelination in the cat by intraneural injection. ${ }^{13}$ Taken together these observations suggest that autoimmunological mechanisms play a role in the

\footnotetext{
Address for reprint requests: Troels Staehelin Jensen, MD., Ph.D., Department of Neurology, Rigshospitalet, Blegdamsvej 9, DK-2100 Copenhagen $\varnothing$, Denmark.
}

Received 19 February 1988 and in revised form 4 May 1988. Accepted 13 May 1988 nerve destruction in patients with combined MGUS and neuropathy. From the fact that autoimmune disorders are linked to certain tissue types and genetic predisposition, a familial occurrence of combined MGUS and neuropathy would be expected. Consistent with this notion Bussis $e t a^{14}$ recently reported the occurrence of peripheral neuropathy and paraproteinaemia of IgM in a mother and her son. This study reports coexisting peripheral neuropathy and IgM gammopathy in a brother and a sister.

\section{Case reports}

Cases 1 and 2 were the 3rd and 5th child of eight siblings born to healthy parents. One sister died at the age of 37 years from tuberculosis. Neither the deceased sister nor the healthy five other siblings had any known neurological disorder. However, it was not possible to examine the other siblings.

Case 1 A white female was born 1916 with a congenital bilateral hip luxation and early development of bilateral hip arthrosis. At the age of 62 she had a sudden episode of speech disturbance and headache. A four vessel cerebral arteriogram was normal. She was treated with a thrombocytaggregation inhibitory agent for 6 years without any intervening transient cerebral ischaemic attacks. From the age of 68 she gradually noticed pricking and sticking sensations in the feet. One year later the paraesthesias had ascended to mid thigh and appeared in the finger tips. On examination at the age of 69 years in 1985 she had slight 
weakness of toes and feet but otherwise strength was normal. Both biceps jerks were depressed and the triceps, radial, knee and ankle jerks were all absent. There was a stocking loss for all sensory modalities. She had a slight intention tremor of both hands but no truncal or limb ataxia.

An IgM, kappa $M$ component was demonstrated in the blood, S-IgM being 10.7 $\mu \mathrm{mol} / 1$ (normal range 0.5-1.6 $\mu \mathrm{mol} / \mathrm{l})$. IgG and IgA concentrations were normal. The bone marrow and the cellular elements of the peripheral blood were normal. A radiological survey of the bones showed no osteolytic or osteosclerotic areas. The results of nerve conduction velocity studies indicated both axonal and demyelinating neuropathy with marked reduction of motor and sensory nerve conduction velocity (less than $25 \mathrm{~m} / \mathrm{s}$ in median and peroneal nerves) and small or absent sensory potentials. During a 2 year observation period there was a gradual progression of neurological deficits. On examination in August 1986 at the age of 70 she had moderate weakness and atrophy of distal muscles in the extremities with a stocking-glove sensory loss in all modalities. Deep tendon reflexes were lost and a slight limb and truncal ataxia was present.

Case 2 A white man born in 1927 experienced episodes of numbness, pins and needles, itching and a burning sensation in the feet and legs from the age of 33 years. Six years later he noticed a progressing weakness in the legs and hands and his gait became unsteady. On examination in 1982 at the age of 55 years he had a moderate symmetrical atrophy and weakness of the distal muscles in all extremities. The tendon reflexes were lost and he had a stocking-glove sensory loss in all sensory modalities with allodynia in fingers and feet. His arms and legs were moderately ataxic and a bilateral hand tremor made worse by movement was present. He walked wide-based and could only do so supported by two sticks. An IgM lambda $\mathbf{M}$ component was demonstrated. Serum IgM was $14.5 \mu \mathrm{mol} / 1$. The bone marrow was normal and radiology of the bones showed no abnormalities. Neurophysiological examination suggested a primarily demyelinating neuropathy with pronounced reduction in motor and sensory nerve conduction velocities (less than 14 $\mathrm{m} / \mathrm{s}$ in median and sural nerves). Treatment with several combinations of plasmaphoresis, chlorambucil, cyclophosphamide and prednisolone had no effect on the neuropathy which gradually progressed during a 4 year period. He was admitted to hospital in June 1986 with signs of a mediastinal tumour and a superior vena cava syndrome. His condition deteriorated rapidly and he died 1 month after admission. Necropsy revealed an adenocarcinoma in the right apical lung with mediastinal and cervical metastases.

\section{Methods}

For histopathological studies a $25 \mathrm{~mm}$ length of a sural nerve was removed in toto, just proximal to the lateral malleolus and deep skin biopsies $(5 \times 5 \mathrm{~mm})$ were performed $5 \mathrm{~cm}$ proximal to the lateral malleolus. The sural nerve biopsy specimens were fixed in $2 \%$ buffered glutaraldehyde, postfixed in $1 \%$ buffered osmium tetroxide dehydrated and embedded in either paraffin or Epon. Cross sections 1-4 $\mu \mathrm{m}$ thick were stained with paraphenylene-diamine, hematoxylin-eosin, PAS, toluidin or Congo Red. Teased fibre analysis was carried out on sural nerve specimens pre- pared as above but were in addition glycerinated in $60 \%$ glycerol. Immunofluorescence studies were carried out as described previously. ${ }^{915}$ Cryostat sections of skin and sural nerve (Case 2) were stained with a direct immunofluorescence technique using fluorescein isothiocyanateconjugated rabbit antibodies to human IgG, IgA, IgM, kappa and lambda chains and C3-complement components. ${ }^{16}$ The reagents were used at a dilution of $1: 10$. For identification of nerve elements in the skin specimens, skin sections were stained for neurofilament using a peroxidaseantiperoxidase technique. ${ }^{17}$

Sera from the two patients were examined for immunoreactivity against components in peripheral nerves by an indirect immunofluorescence method. The sera in dilution 1:5 were applied to cryostat sections of human nerve specimens obtained at postmortem examination about $6 \mathrm{~h}$ after death. In addition the sera from the two siblings as well as sera from nine other patients with an IgM M protein but without peripheral neuropathy were examined for the presence of antibodies against bovine peripheral nerve myelin (PNM) with a slightly modified ELISA technique. ${ }^{18}$ Briefly, microtitre plates were coated with $0.1 \mathrm{ml} /$ well of PNM (80 $\mu \mathrm{g} / \mathrm{ml})$ in $0.05 \mathrm{M}$ sodium carbonate buffer ( $\mathrm{pH} \mathrm{9.6)}$ and then incubated with sera. A concentration of $15 \mathrm{mg} / \mathrm{l}$ of IgM in each sample was used because it led to optimal discrimination between positive and negative controls. Controls were included on each plate and consisted of: (a) serum from a patient with previously detected high antibody activity against peripheral nerve and (b) pooled serum from 200 blood donors; and (c) serum from a patient with monoclonal gammopathy but without neuropathy. Controls were included on each plate. Alkaline phosphatase conjugated antihuman IgM antiserum (Sigma, St Louis, USA) was then applied. After washing and enzyme reaction was carried out the absorption was measured.

\section{Results}

Case 1 The sural nerve consisted of 10 fascicles with an endoneurial area of $0.67 \mathrm{~mm}^{2}$. The total number of myelinated fibres was decreased to 1931 fibres (normal mean: 7,000 fibres) with a particular reduction of large myelinated fibres (fig 1). Teased fibre preparation disclosed swelling and fragmentation of myelin into balls and ovoids and with multiple areas of segmental demyelination. Amyloid deposits and inflammatory cells were not seen. Immunohistological studies were not carried out on sural nerve specimens but direct immunofluorescence examination showed binding of IgM to nerve myelin in cutaneous nerves (fig 1), whereas $\operatorname{IgA}$, IgG or C3 complement did not bind. Indirect immunofluorescence showed binding of S-IgM to normal peripheral nerve myelin.

Case 2 The sural nerve specimen showed a marked reduction of especially large myelinated fibres (fig 2). Teased fibre analysis revealed segmental demyelination with swelling and fragmentation presenting as balls and ovoids of myelin. Amyloid deposits and inflammatory cell infiltration were not seen. On direct 

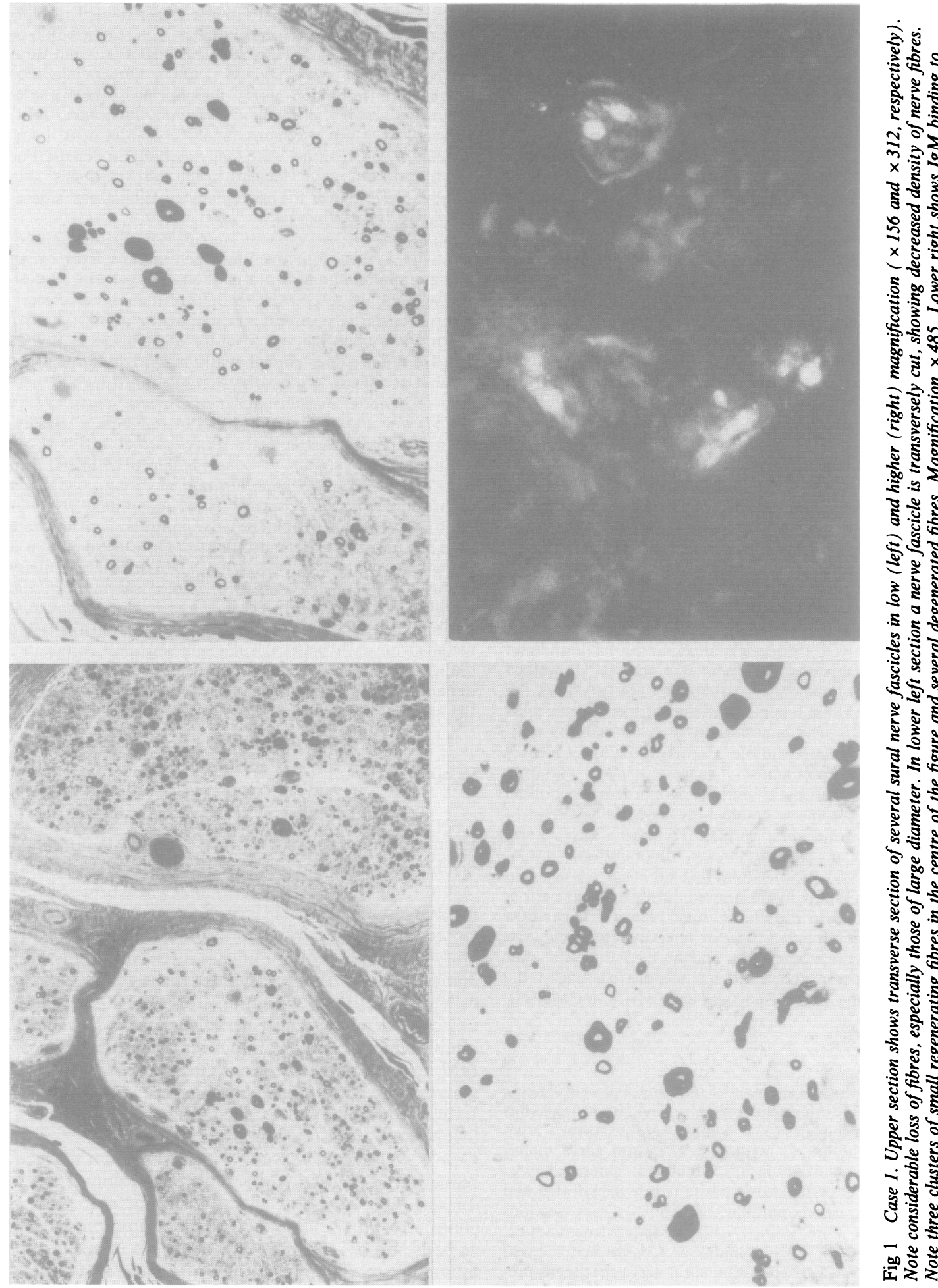
i

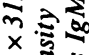

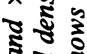

8 क

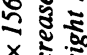

$x$

ฐ)

:

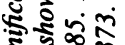

है $\bar{x} x$

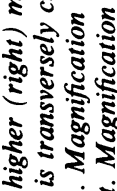

ปับั้

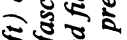

ฐั

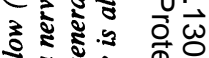

ธ

इ 5 ชै

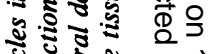

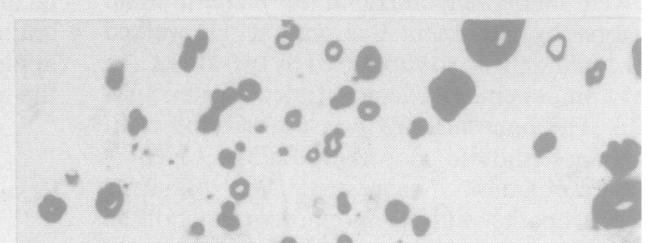

ธัँ 产

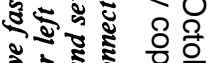

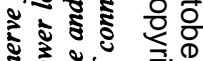

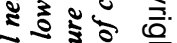

ฐ

ปั่

ปัฐ ฐ

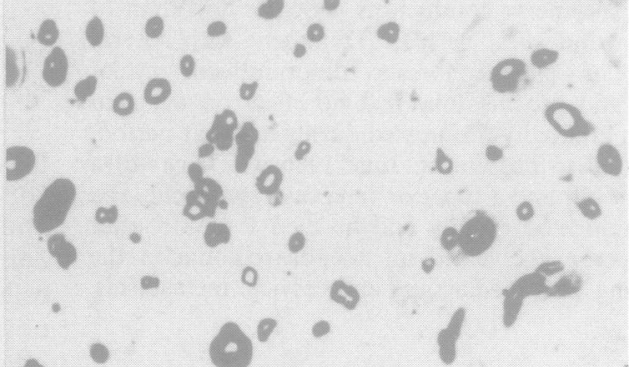

क छ ญ

क ष

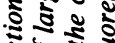

के

\% ป

के

ลิำ

政

के ङ

के क्षे

ฐ

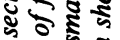

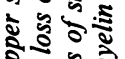

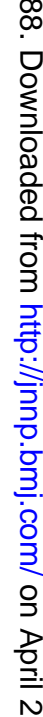

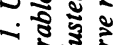

รัฐ ญ

डัญ ฐ

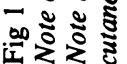



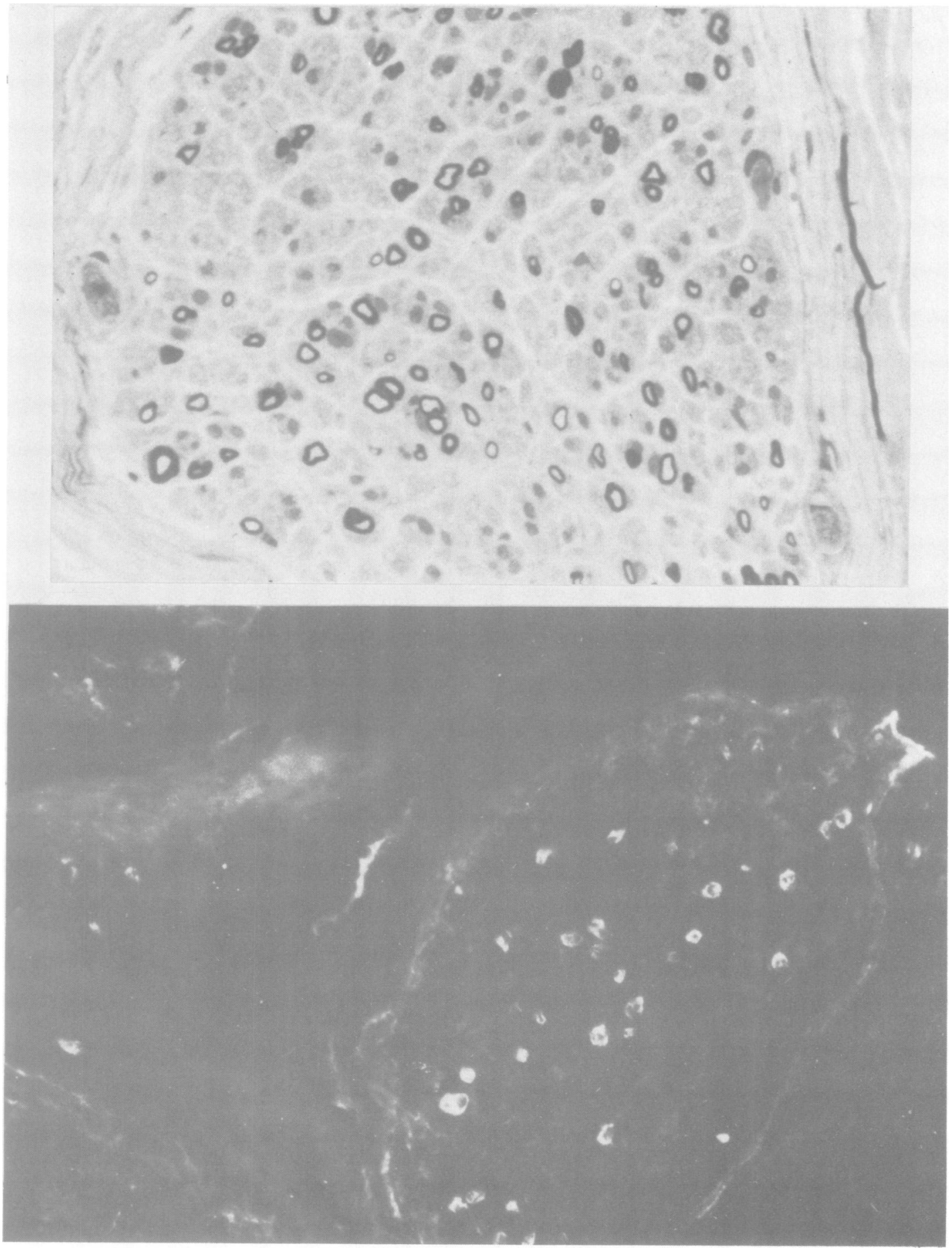

Fig 2 Case 2. Upper section: Transverse section of sural nerve fascicle showing reduction of nerve fibres particularly large diameter fibres. Magnification $\times 282$. Lower section: Direct immunofluorescence staining of sural nerve showing binding of IgM to myelin sheaths. Magnification $\times 140$. 


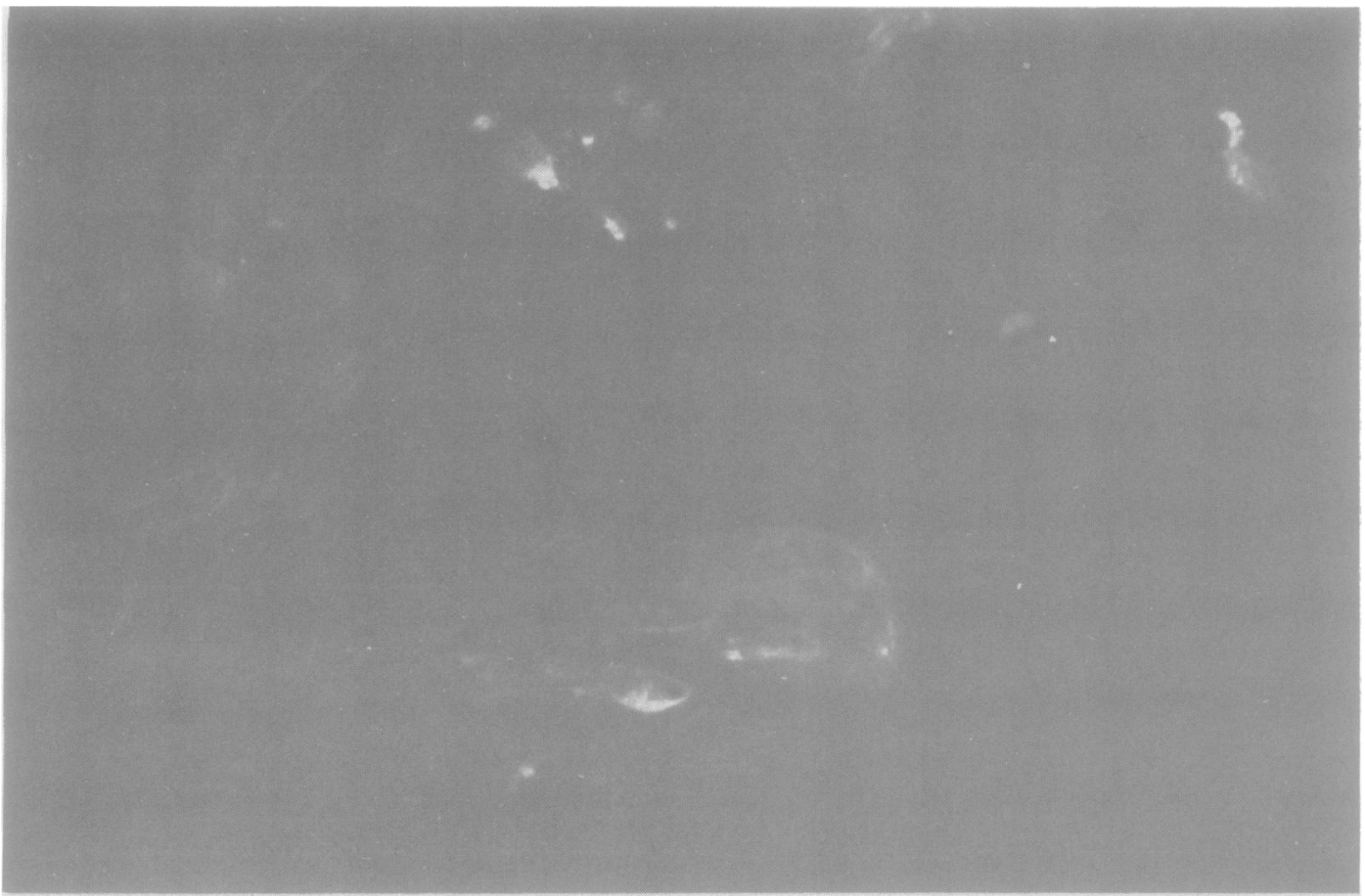

Fig 3 Case 2. Upper section: Direct immunofluorescence examination of skin biopsy specimen showing binding of IgM to cutaneous nerve fibres. Lower section: Similar section as upper one stained for neurofilament; see method for further details. Magnification $\times 282$ in both sections. 

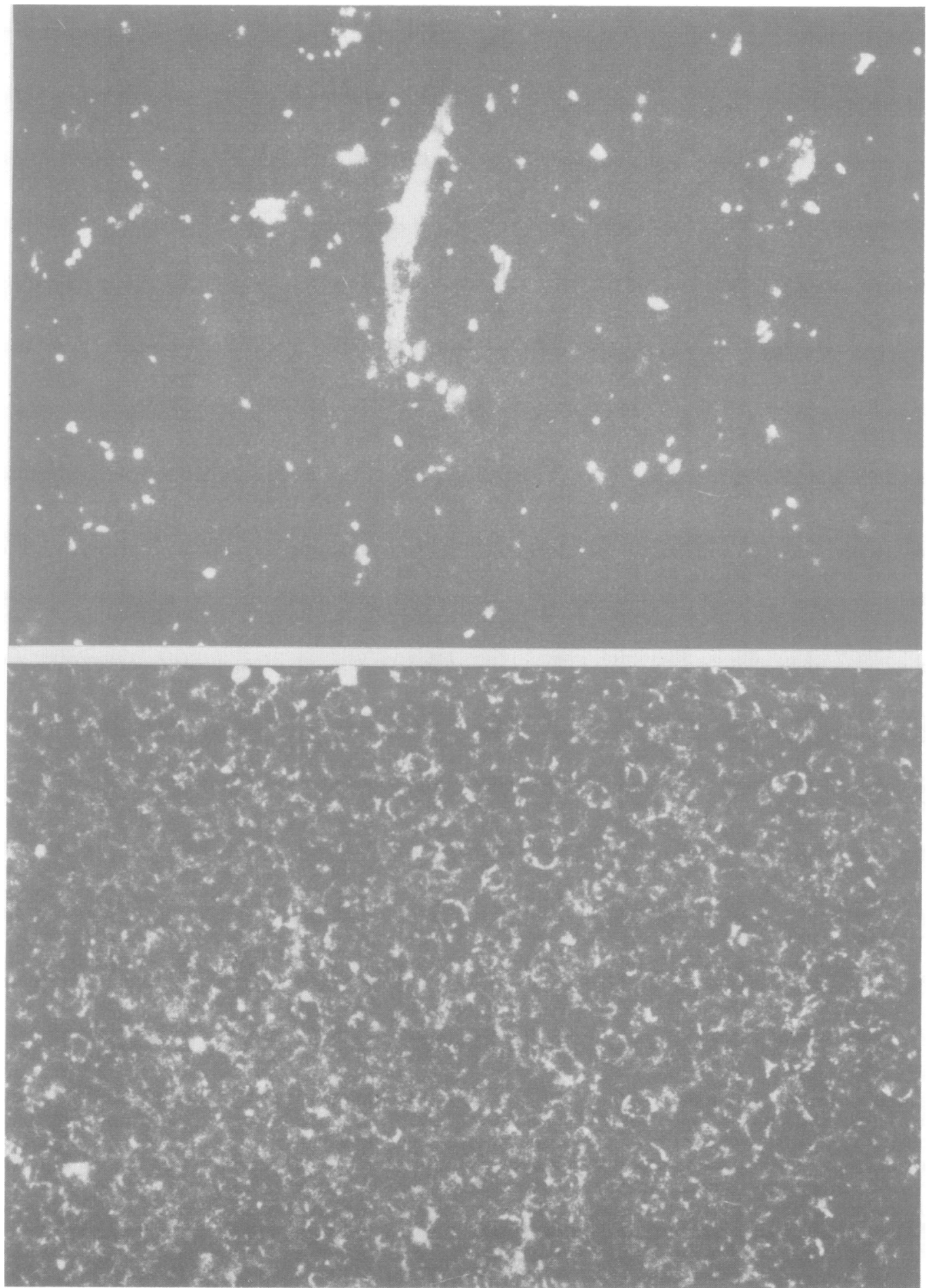

Fig 4 Case 2. Upper section: Direct immunofluorescence of cerebral cortical tissue showing no binding of IgM to neural structures but intense immunofluorescence of a small vessel. The scattered star-like fluorescence represent autofluorescence in cell nuclei. Lower section: Indirect immunofluorescence of normal spinal cord tissue incubated with serum from case 2 showing binding of patients serum to spinal white matter. Magnification $\times 282$ in both sections. 
Table Summary of clinical and immunological features in 11 patients with IgM M proteins

\begin{tabular}{|c|c|c|c|c|c|c|c|}
\hline \multirow[b]{2}{*}{$\begin{array}{l}\text { Case } \\
\text { no. }\end{array}$} & \multirow[b]{2}{*}{$\begin{array}{l}\text { Sex/age } \\
(y r)\end{array}$} & \multirow[b]{2}{*}{$\begin{array}{l}\text { Clinical } \\
\text { diagnosis }\end{array}$} & \multicolumn{2}{|c|}{ Monoclonal protein } & \multirow[b]{2}{*}{$\begin{array}{l}P N M^{*} \\
A b\end{array}$} & \multirow{2}{*}{$\begin{array}{l}\text { Direct } \\
\text { fluorescence } \\
\text { Ig skin deposit }\end{array}$} & \multirow{2}{*}{$\begin{array}{l}\text { Indirect } \\
\text { fluorescence } \\
S \text {-IgM binding }\end{array}$} \\
\hline & & & Type & $\begin{array}{l}\text { Concentration } \\
(\mathrm{g} / \mathrm{l})\end{array}$ & & & \\
\hline 1 & $F / 70$ & MGUS + & IgM, kappa & $3 \cdot 6$ & 0.414 & IgM, kappa & Myelin \\
\hline 2 & M/59 & $\begin{array}{l}\text { neuropathy } \\
\text { MGUS + } \\
\text { neuropathy }\end{array}$ & IgM, lambda & $13 \cdot 0$ & 0.614 & $\begin{array}{l}\text { myelin binding } \\
\text { IgM, lambda } \\
\text { myelin binding }\end{array}$ & Myelin \\
\hline 3 & F/77 & MGUS & IgM, kappa & $79 \cdot 2$ & $\mathbf{0}$ & $\begin{array}{l}\text { IgM, kappa } \\
\text { connective tissue }\end{array}$ & $\begin{array}{l}\text { Connective tissue incl. } \\
\text { peri/endoneurium }\end{array}$ \\
\hline 4 & $\mathbf{M} / 80$ & MGUS & IgM, kappa & $21 \cdot 6$ & $\mathbf{0}$ & $\begin{array}{l}\text { IgG, kappa and IgA, } \\
\text { kappa in dermoepidermal } \\
\text { function }\end{array}$ & None \\
\hline $\begin{array}{l}5 \\
6\end{array}$ & $\begin{array}{l}M / 75 \\
M / 62\end{array}$ & $\begin{array}{l}\text { MGUS } \\
\text { MGUS }\end{array}$ & $\begin{array}{l}\text { IgM, kappa } \\
\text { IgM, kappa }\end{array}$ & $\begin{array}{l}3 \cdot 6 \\
9 \cdot 6\end{array}$ & $\begin{array}{l}0.079 \\
0 \cdot 100\end{array}$ & $\begin{array}{l}\text { None } \\
\text { Reticular structures nuclei } \\
\text { and collagen filaments }\end{array}$ & $\begin{array}{l}\text { None } \\
\text { Connective tissue and } \\
\text { nuclei }\end{array}$ \\
\hline 7 & $\mathbf{M} / 50$ & $\begin{array}{l}\text { Postinfectious } \\
\text { neuropathy }\end{array}$ & IgM, kappa & $8 \cdot 5$ & 0.055 & None & $\begin{array}{l}\text { Weak binding to } \\
\text { endoneurium }\end{array}$ \\
\hline 8 & $F / 73$ & MGUS & IgM, lambda & $3 \cdot 5$ & 0.089 & $\begin{array}{l}\text { IgA, IgM and complement } \\
\text { C3 in dermoepidermal } \\
\text { function }\end{array}$ & None \\
\hline 9 & $\mathbf{F} / 48$ & $\begin{array}{l}\text { Waldenström's } \\
\text { disease }\end{array}$ & IgM, lambda & $94 \cdot 5$ & 0 & None & None \\
\hline 10 & $F / 40$ & $\begin{array}{l}\text { Waldenström's } \\
\text { disease }\end{array}$ & IgM, lambda & $48 \cdot 6$ & 0.063 & None & Not performed \\
\hline 11 & $\mathrm{M} / 72$ & MGUS & IgM, lambda & 7.6 & $0 \cdot 154$ & None & None \\
\hline
\end{tabular}

*Antibody activity against peripheral nerve myelin as measured by absorption in the ELISA system.

immunofluorescence examination of sural nerve (fig 2) and skin biopsy specimens (fig 3) binding of IgM lambda to myelin sheaths was observed. Indirect immunofluorescence showed that the serum contained an IgM, $M$ protein directed against normal peripheral nerve myelin.

Immunofluorescence staining using FITCconjugated antihuman IgM revealed no deposits in specimens of cerebral tissue but a marked immunofluorescence of cerebral vessels (fig 4). When sections of normal spinal cord tissue obtained from necropsy cases were incubated in vitro with the patients serum containing the $\mathbf{M}$ protein binding was observed in the white matter of spinal cord (fig 4). Sera from Case 1 and 2 contained antibodies against PNM as measured by ELISA. In contrast, in nine other patients with IgM monoclonal gammopathy (five patients with MGUS but no associated neuropathy, two patients with Waldenström's disease and one patient with a postinfectious neuropathy) there was no significant antibody activity in serum directed against PNM (table).

\section{Discussion}

Our two siblings had a benign IgM monoclonal gammopathy and an associated mixed axonal and demyelinating neuropathy, on account of electrophysiological and morphological criteria.

Immunopathological studies showed binding of IgM to nerve elements in skin in both patients and to sural nerve in one patient. These features are similar to previous reported neuropathies and IgM mono- clonal gammopathies, in which an immunological mediated disorder has been suggested (for review see refs ${ }^{68}$ ). The finding of antibody activity against peripheral nerve tissue in the present two cases and the observation that their serum IgM immunostained normal peripheral nerves in vitro suggest that the $M$ protein had autoantibody activity directed against peripheral nerve myelin. However, the pathological significance of these antibodies is not clear. Thus, recent studies have shown that antibodies against? PNM are found in approximately $15 \%$ of healthy blood donors without signs of neuropathy as well as in patients with polyneuropathy but without gammopathy (unpublished observations). Apparently, there is no simple relationship between antibodies against PNM and $M$ protein associated neuropathy. Previous studies of patients with IgM, M proteins and neuropathy indicate that the $M$ proteins may be directed towards different targets of nerve structures such as chondroitin sulphate ${ }^{12}$ and myelin associated glycoprotein (MAG). ${ }^{19} 20$ Subsequent work has shown that the antibody is directed against antigenic determinants shared by various structures in normal human peripheral nerves such as gangliosides and other glycoproteins. ${ }^{20}$ Possible antigenic targets such as MAG and chondroitin sulphate were not tested in the present cases, but the clinical and pathological features of our patients are similar to those described with anti MAG antibodies.

The familial occurrence of serum IgM, M proteins and associated neuropathy raises questions about the underlying disorder. Previous studies have noted a familial occurrence of both lymphoproliferative disor- 
ders with gammopathy and of benign monoclonal gammopathy. ${ }^{21-23}$ Paraproteins within different members of affected families may vary. ${ }^{1421-23}$ In our two cases the light chain type of the IgM, M protein was classified as kappa and lambda, respectively.

Bussis $e t$ al $^{14}$ described a mother and a son with high serum IgM, an $\mathbf{M}$ component and an associated neuropathy. In their study the immunopathological examination showed the presence of anti MAG antibodies in one afflicted member, but was not characterised in the other family member. Given the fact that autoimmune disorders may occur in certain families, the present cases and those reported by Bussis et al $^{14}$ may have a genetically predisposed altered immune regulation with antibody-mediated neuropathy or alternatively an abnormality of blood nerve barrier components. A genetic determined susceptibility to an autoimmunologically mediated neuropathy is supported by the recent observation that the distribution of IgG heavy chain $\mathrm{Gm}$ allotypes in patients with demyelinating neuropathy and associated IgM monoclonal autoantibodies are different from the $\mathrm{Gm}$ phenotypes seen in a normal population. ${ }^{24}$

It is still unknown how immunocompetent cells and antibodies can induce an antigen-antibody reaction against antigenic determinants on the other side of the blood-nerve-barrier. It has been observed that endothelial cells lining the vascular compartment may act as antigen-presenting cells ${ }^{25}$ and thus represent the early stages for blood-nerve-barrier damage, which ultimately may allow the passage of antibodies and/or immunocompetent cells across the blood-nervebarrier. It is of interest to note that direct immunofluorescence study of brain specimens from our case 2 showed binding of IgM to cerebral vascular tissue. This may represent a specific binding and thus support the view that endothelial cells occasionally may serve as antigen-presenting cells. Studies on blood-nerve-barrier properties in patients with $\mathbf{M}$ proteins and neuropathy and in animals with experimental allergic neuritis may be rewarding in clarifying the pathogenesis of neuropathies in patients with monoclonal gammopathies. It should be noted that while our studies are in agreement with previous reports showing binding of IgM proteins to myelinated tissue we do not know whether such binding is secondary to a preexisting blood-nervebarrier damage or is the result of a primary destruction of myelinated tissue followed by blood-nervebarrier damage and eventually antibody access to antigenic determinants in nerve fibres.

\section{References}

1 Delauche MC, Clauvel JP, Seligmann M. Peripheral neuropathy and plasma cell neoplasias: a report of 10 cases. Br J Haematol 1981;48:3883-92.

2 Dellagi K, Dupouey P, Brouet JC, et al. Waldenström's macroglobulinemia and peripheral neuropathy: a clinical and immunologic study of 25 patients. Blood 1983;62:280-5.

3 Iwashita H, Argyrakis A, Lowitzsch IC, Sparr FW. Poly- neuropathy in Waldenström's macroglobulinemia. $J$ Neurol Sci 1974;21:341-54.

4 Julien J, Vital C, Vallot JM, Lagueny A, Deminiere C, Darriet D. Polyneuropathy in Waldenström's macroglobulinemia. Arch Neurol 1978;35:423-5.

5 McLeod JG, Walch JC, Pollard JD. Neuropathies associated with paraproteinemias and dysproteinemias. In: Dyck PJ, Thomas PK, Lambert EH, Bunge R, eds. Peripheral Neuropathy. London: W.B. Saunders Comp., 1984;1947-65.

6 Kelly JJ. Peripheral neuropathies associated with monoclonal proteins: a clinical review. Muscle Nerve 1985;8:138-50.

7 Smith IS, Kahn SN, Lacey BW, et al. Chronic demyelinating neuropathy associated with benign IgM paraproteinemia. Brain 1983;106:169-95.

8 Latov N. Immunological abnormalities associated with chronic peripheral neuropathies: plasma cell dyscrasia and neuropathy. In: Behan P, Spreafico F, eds. Neuroimmunology. New York: Raven Press, 1984:261-73.

9 Jønsson V, Jensen TS, Friis ML, et al. Immunoglobulin deposits in peripheral nerve endings detected by skin biopsy in patients with IgM M-proteins and neuropathy. Neurology 1987;37:303-6.

10 Nemni R, Galassi G, Latov N, et al. Polyneuropathy in nonmalignant IgM plasma cell dyscrasia: a morphological study. Ann Neurol 1983;14:43-54.

11 Abrams GM, Latov N, Hays AP, Sherman W, Zimmerman EA Immunocytochemical studies of human peripheral nerve with serum from patients with polyneuropathy and paraproteinemia. Neurology 1982;32:821-6.

12 Freddo L, Hays AP, Sherman WH, Latov N. Axonal neuropathy in a patient with IgM $M$-protein reactive with nerve endoneurium. Neurology 1985;35:1321-5.

13 Hays AP, Latov N, Takatsu M, Sherman WH. Experimental demyelination of nerve induced by serum of patients with neuropathy and an anti-MAG IgM M-protein. Neurology 1987;37:242-56.

14 Busis NA, Halperin JJ, Stefansson K, et al. Peripheral neuropathy, high serum IgM and paraproteinemia in a mother and son. Neurology 1985;35:679-83.

15 Jønsson V, Schrøder HD, Jensen TS, et al. Autoimmunity related to IgM monoclonal gammopathy of undetermined significance. Acta Med Scand 1988;223:255-61.

16 Nairn, RG. Fluorescent Protein Tracing. Edinburgh: Churchill Livingstone, 1969.

17 Sternberger LA. Immunocytochemistry. Englewood Cliffs NJ: Prentice Hall, 1979.

18 Ernerudh J, Brodtkorp E, Olsson T, Vedeler CA, Nyland H, Berlin G. Peripheral neuropathy and monoclonal IgM with antibody activity against peripheral nerve myelin; Effect of plasma exchange. $J$ Neuroimmunol 1986;11:171-8.

19 Ilyas AA, Quarles RH, MacIntosh TD, et al. Igm in a human neuropathy related to paraproteinemia binds to a carbohydrate determinant in the myelin-associated glycoprotein and to a ganglioside. Proc Natl Acad Sci USA 1984;81:1225-9.

20 Mendell JR, Sahenk Z, Whitaker JN, et al. Polyneuropathy and IgM monoclonal gammopathy: studies on the pathogenetic role of antimyelin-associated glycoprotein antibody. Ann Neurol 1985;17:243-54.

21 Axelsson U, Hallen J. Familial occurrence of pathological serumproteins of different gammaglobulin groups. Lancet 1965; ii:369-70.

22 Seligman M, Danon F, Mihaesco C. Immunoglobulin abnormalities in families of patients with Waldenström's macroglobulinemia. Am J Med 1967;43:66-83.

23 Zawadzki ZA, Aizawa Y, Kraj MA, Haradin AR, Fisher B. Familial immunopathies: report of nine families and survey of literature. Cancer 1977; 40:2094-101.

24 Kahn SH, Pandey JP. IgG heavy chain (Gm) allotypes in demyelinating polyneuropathy associated with MAG-binding monoclonal IgM autoantibodies. Ann Neurol 1987;21:507-9.

25 Pardridge WM. Biochemistry of the human blood-brain barrier, pp 90-94. In: Pardridge WM, moderator. Blood-brain Barrier: Interface Between Internal Medicine and the Brain. Ann Int Med 1986;105:88-95. 